
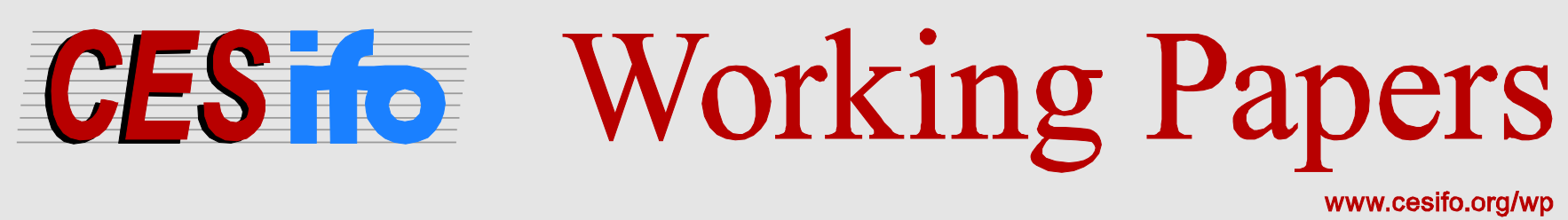

\title{
Oil and Vinegar: A Positive Fiscal Theory of the Euro Crisis
}

\author{
Charles B. Blankart
}

CESIFO WORKING PAPER NO. 4426

CATEgory 1: Public FinAnCE

OCTOBER 2013
An electronic version of the paper may be downloaded
- from the SSRN website: Www.SSRN.com
- from the RePEc website: Www.RePEc.org
- from the CESifo website: www.CESifo-group.org/wp

\section{CESifo}




\title{
Oil and Vinegar: A Positive Fiscal Theory of the Euro Crisis
}

\begin{abstract}
The theory of optimal currency areas states that a currency union may succeed if the participating countries have complementary industry structures. If this is not the case a currency union does not, inevitably, have to fail because market forces will induce adjustments of the industry structures that will eventually lead to a successful currency union (see e.g. De Grauwe, 2006). This optimism is, however, not warranted for the euro. The euro has now been in a crisis for more than three years and a self-correcting mechanism leading out of the crisis is not in sight. The reason is that the euro union does not suffer from unadjusted industries, but from unadjusted governments. While industries adjust under the command of the invisible hand of the market in a currency union, this is not necessarily the case for governments. The general point of this paper is that countries with incompatible governments remain inimical in a currency union. They generate externalities and crises which cannot be eliminated as well in a political union.

Assume that two countries traditionally cooperate in an economic union. Their governments are financially independent. They "go Dutch". A currency union, such as the euro union, is different. It opens not only the option of a closer economic cooperation, but it also allows for a joint cash management so that each government has the temptation to live on the other's costs and hence to generate negative externalities on the other. The governments may be aware of this trap. They conclude a Treaty in order to prevent their mutually destructive behavior. But the Treaty turns out to be non-enforceable and therefore unable to stop the infringements by mutual externalities, this being the essence of the euro crisis. Therefore the governments should withdraw and return to an economic union without externalities.
\end{abstract}

JEL-Code: H120, H630, H770, H870, F360.

Charles B. Blankart

Department of Economics

Humboldt University Berlin

Tristanstrasse $17 \mathrm{D}$

Germany - 14109 Berlin

charles@blankart.net

To be published in Kyklos 2013. 


\title{
Oil and Vinegar: A Positive Fiscal Theory of the Euro Crisis
}

\author{
Charles B. Blankart*
}

\begin{abstract}
He who wishes to bake fine cakes
All seven ingredients must have Butter and salt, shortening and eggs Milk and flour, with saffron all exhort The oven a golden colour to give But He who is an ingredient short Will bake no fine cakes.
\end{abstract}

\section{THE EURO FROM AN EXTERNALITIES POINT OF VIEW}

This paper presents a study of Germany and France, the two core countries of the European Monetary Union. It illustrates why the two countries can successfully cooperate in an economic union under separate currencies and with separate cash management, but create mutually destructive externalities leading to crisis and failure in a monetary union with one currency and joint cash management. The conclusions of the study have, however, a more general application. It is argued that a currency union may succeed if its fiscal institutions are compatible, but that it is likely to generate crises and eventually a failure if it is composed of externality generating fiscal institutions. Germany and France are just two practical examples of this general theory.

Section II explains more in detail, with game theory, the difference between an economic union and a monetary union and why the latter may succeed if its fiscal systems are compatible or fail if its fiscal systems generate mutual externalities.

* Prof. Charles B. Blankart, Humboldt University Berlin, University of Lucerne, CESifo and CREMA email: charles@blankart.net. The author is indebted to $\llbracket$ KVstudents, to an anonymous referee, to Rudolf Blankart, Wolfgang Glomb, Stefan Homburg, Otmar Issing, Christian Kirchner, Achim Klaiber and Christoph A. Schaltegger for helpful comments and to Mats Geiden von Schwarzenburg for editorial help. The paper has been presented at the Swiss Economists Abroad Conference in Lucerne 2012, at the European Public Choice Conference in Zurich 2013, at the Federal Ministry of Public Finance in Berlin 2013, at the Hayek Club in Kiel 2013, at the research seminar of university of Lucerne 2013, at the Public Finance Committee of the German economic association and at the IIPF Conference 2013 in Taormina where the author has greatly benefitted of the participants' comments. 
Section III explains why Germany and France both started as self-sufficient "Oil" regimes in the early Middle Ages, but then have grown apart after the French revolution; why France has adopted a national common pool budget generating budget externalities and "Vinegar" on other budgets while the German states and later Germany remained "Oil states" continuing their previous tradition of self-sufficiency.

Section IV opens the post-World-War-II-history with Winston Churchill's great idea of the "United States of Europe" pronounced in his Zurich Speech of $19^{\text {th }}$ September 1946 (Churchill, 1946). But before rushing so far, a moment of thought is necessary. As the EU member states were aware of the dangers inherent in a monetary union they started with an economic union and separate currencies in 1958 and from there proceeded to monetary cooperation under the European Monetary System (EMS) in the late 1970'ies limiting the exchange rate fluctuations on the one hand and hence allowing, but still limiting, externalities by infringements in each other's resources before they made the final step to the monetary union.

Section V focuses on the Maastricht Treaty of 1992 which eliminated the exchange rate fluctuations by establishing a single currency and provided for safeguard regulations so that no member state should infringe on the other's resources. But these safeguards have been eliminated ex post so that mutual infringements re-appeared and the European Monetary Union resulted in a transfer union with mutual externalities and crises. From the failure of the euro monetary union it can be concluded that a euro political union would not work either.

In section VI it is asked what should be done. Solving the externality problem in a treaty would be first best. But if a treaty is not enforceable mutual withdrawal and a return to an economic union $\mathbb{P} \mathrm{D} \mathbb{E H} \mathrm{EH}$ Hlogical consequence.

\section{AN ECONOMIC UNION AND A MONETARY IN THEORY}

\section{II.1. Oil and vinegar in action}

The paper starts with a purely theoretical model ignoring any real world allusion. Suppose that there are two countries "Oil" and "Vinegar" as depicted in table 1. Oil and Vinegar form an economic union in an integrated single market for goods, services, labour and capital. Oil pursues a policy of balanced budgets and price stability whereas Vinegar pursues a policy of permanent budget deficits and inflation (an explanation why governments may behave in this way will be provided in section III). As the Vinegar government is permanently plagued with a shortage of revenues, it has a temptation to go off budget within its currency area, i.e. to externalize its deficits to parafiscal institutions, to subcentral governmental units, to taxpayers via higher taxes and public debt and inflation over 
Table 1

An economic and a monetary union compared

\begin{tabular}{|c|c|c|}
\hline \multicolumn{3}{|c|}{ Economic Union (E) two countries, two currencies } \\
\hline Oil state (stability regime) & \multicolumn{2}{|c|}{ Vinegar state (inflation regime) } \\
\hline \multicolumn{3}{|c|}{ Flexible Exchange rates } \\
\hline \multicolumn{3}{|c|}{ Good friends "go Dutch"; no externalities } \\
\hline \multicolumn{3}{|c|}{ Monetary Union: Two countries, one currency ,€’” } \\
\hline \multicolumn{3}{|c|}{ Joint cash management } \\
\hline \multicolumn{2}{|l|}{ Oil state } & Ir state \\
\hline \multicolumn{3}{|l|}{ Four Alternatives } \\
\hline A. Oil central bank & Transfer Union & A. Vinegar central bank \\
\hline B. Vinegar central bank & Transfer Union & B. Vinegar central bank \\
\hline C. Oil central bank & Maastricht Union & C. Oil Central Bank \\
\hline D. Political central bank & double transfer union & D. Political central bank \\
\hline
\end{tabular}

Source: Own compilation.

the money printing press. Vinegar cannot, however, externalize its deficits to Oil as it is assumed that the two countries have different currencies. Whenever Vinegar tries to extend its money supply to increase its imports, its foreign exchange rate falls compared to the exchange rate of Oil, so that nothing can be gained by Vinegar's policy. The different policies of Oil and Vinegar do, however, not prevent the inhabitants of the two countries to be good friends. An Oil citizen may have lunch with a Vinegar citizen, and each pays in his own currency at the given exchange rate. The two friends "go Dutch", and this is, indeed, the reason why they are good friends as depicted in the upper part of table 1 . No externalities are generated.

Now suppose that the two governments decide to form a currency union with the "euro" as a common currency (see lower part of table 1). The governments discuss beforehand how to make the best choice of a monetary order.

- In a first proposal, the governments consider case $A$ in which both governments adopt the euro, but leave the monetary authority to each government. Each government issues euro bank notes as they did before with national bank notes. Oil prints bank notes to maintain its stability policy in its area. Vinegar prints so many bank notes that it can finance its budget deficit. The inflation produced in Vinegar will allow Vinegar to benefit from budget balancing and stable prices in the Oil country. The result will be a transfer union with a rate of inflation that is situated somewhere in between that of the former Oil and Vinegar regimes. Part of the purchasing power is exported from Vinegar to Oil whereas goods and services flow from Oil to Vinegar. An externality is generated by Vinegar to the disadvantage of Oil.

- In case $B$ the two governments become aware that a common central bank is needed to establish a unitary monetary policy. Vinegar takes the initiative 
and approaches Oil to convince it that Vinegar's central bank should become the common central bank. But Oil is skeptical. It predicts that the outcome will not be much different from case A. In case B a rate of inflation would be produced which is situated between that of the former independent Oil and Vinegar regimes as in case $\mathrm{A}$.

- Case C emerges because the Oil government rejects Vinegar's proposal B. It says: I shall endorse the step from the economic union $\mathrm{E}$ to the monetary union only if our Oil central bank is given full authority over the money supply in both countries. This is the essence of case C. Though Vinegar still prefers solution $\mathrm{B}$, it is in a take-it-or leave-it situation inducing it to agree to $\mathrm{C}$ rather than to remain in the economic union $\mathrm{E}$. In the following Treaty of Maastricht, Vinegar agrees to give the Oil central bank the full authority and political independence over the common money supply. Budget and money supply are assessed in such a way that price stability is generated in both countries. Vinegar can no longer increase the money supply to finance its budget deficit. It has to reorganize its finances in order to establish a balanced budget.

- Case D: With solution C it cannot, however, be prevented that Vinegar still prefers B to C. B is still in the game as long as no exogenous enforcer exists who categorically excludes B. Therefore starting sequentially from solution $\mathrm{C}$ Vinegar decides to defect by infiltrating its own policy B into C. Oil makes the best of this uncomfortable situation and responds by defecting too and playing $D$, the game of an unrestricted political central bank. As Vinegar is better off under $\mathrm{D}$ than under $\mathrm{E}$, a return to $\mathrm{E}$ is not feasible under unanimity rule.

The choices between E, C, B and D are summarized in equations (1) and (2) for Oil and Vinegar individually:

Cooperatively:

\begin{tabular}{|ll|}
\hline Oil: & $\mathrm{C}>\mathrm{E}$ \\
Vinegar: & $\mathrm{C}>\mathrm{E}$ \\
\hline
\end{tabular}

non-cooperatively:

\begin{tabular}{|ll|}
\hline Vinegar: & B $>$ C \\
Oil: & D $>$ B \\
\hline
\end{tabular}

Equation (1) describes the cooperative game. Oil and Vinegar enter a monetary union if $\mathrm{C}>\mathrm{E}$ for each country. Strictly speaking the benefits of the currency union are assumed to be net benefits equal to gross benefits. This assumption is 
plausible for Oil, which simply extends its existing fiscal-monetary regime to the currency union. For Vinegar, however, net and gross do not necessarily coincide.

$$
\begin{gathered}
\text { Oil's benefit }=(C-E) \\
\text { Vinegar's benefit }=\left(C_{n e t}-E\right) .
\end{gathered}
$$

For obtaining the net benefits $\mathrm{C}_{\text {net }}$ Vinegar has to give up its inherited fiscal institutions and to adapt them to Oil's institutions. It has to incur non-negligible adjustment costs leading to a reduced benefit $\left(\mathrm{C}_{\mathrm{net}}-\mathrm{E}\right)<(\mathrm{C}-\mathrm{E})$ for Vinegar.

Now return to equations (1) and (2). The contract $C$ suggests at a first sight that $\mathrm{C}$ is a cooperative game. This would indeed be the case if both countries are Oil countries. But with Oil and Vinegar in combination the situation is different. The reappearance of B reveals that Oil and Vinegar are non-complementary and the game is non-cooperative (unless the exogenous enforcer mentioned before comes and eradicates B). As long as B exists, Oil reluctantly stands by while Vinegar defects towards B and induces the common central bank to make large transfer payments to Vinegar (and to other countries who adopt Vinegar's example). So Vinegar generates externalities against Oil. In its reluctance, Oil can secure that the receiver countries receive the money on conditions of a strict internal austerity policy causing depression, unemployment and hate against the donor country Oil. So the euro crisis becomes a torrent of tears for the recipient countries and their populations that could be avoided if they were able to make their choices in their own national currencies under the self-responsibility of an economic union. What can Oil do? Instead of lamenting, Oil can give up its principles and play D, which is obnoxious for Vinegar. But as long as Vinegar is better off under $\mathrm{D}$ than under $\mathrm{E}$ a unanimous return from there to $\mathrm{E}$ is not feasible. The crisis is persistent.

The euro crisis starts because Vinegar defects on contract C. Nevertheless it would be wrong to say that Vinegar is the only responsible for the crisis lest we forget "The Problem of Social Costs" by Ronald Coase (1960). In the farmerrancher paradigm, the rancher is the originator of the conflict as his cattle penetrates into the farmer's land and destroys his crop. But Coase argues correctly that both, the rancher and the farmer are responsible for the externality. For without the farmer there is no externality by the rancher. Similarly Oil and Vinegar are both responsible for the externalities generated by the currency union. The purpose of this paper is to find out what can be done to stop these externalities.

The theory proposed here is different from the theory of optimal currency areas by De Grauwe (2006) and others. De Grauwe's monetary union is composed of competitive industries which must adjust under the pressure of the market in a currency union should they not yet be compatible when the currency 
union starts. In the theory proposed here industries are replaced by governments pursuing partially incompatible policies. As there are no market forces there is no automatic adjustment. The externalities persist and cause the crisis and therefore it is relevant to select carefully beforehand which governments are eligible for a currency union.

The general conclusion is

- that two countries may enter a currency union if their institutions do not generate negative externalities or if $\mathrm{C}>\mathrm{E}$ is the globally dominant strategy for both,

- that two countries should not enter a currency union if (at least) one of them generates negative externalities or if $\mathrm{C}>\mathrm{E}$ is mixed with $\mathrm{B}>\mathrm{C}$.

In the latter cases a currency union should not be started. One of the fundamental mistakes with the euro is that its founders missed to make a careful triage between eligible and non-eligible states, between Oil states and Vinegar states so that the crisis could have been avoided.

\section{II.2. Externalities and the theory of the missing egg ${ }^{1}$}

The reader may now understand the deeper reason of the little poem at the outset of this paper. A cook considering baking a cake has to select carefully its ingredients. Otherwise the cake will fail. While this is self-evident, politicians notoriously disregard this simple truth when designing institutions. They inconsiderately mix Oil and Vinegar institutions and assume that they will automatically join to a new and superior institution. But this is not the case: an experienced grocer knows that Oil and Vinegar are different raw materials that are normally immiscible. Oil is hydrophobic, while Vinegar is hydrophilic. If they are mixed together they form an emulsion that does not have a static internal structure. After a while the oily hydrophobic and the watery hydrophilic phase will separate again.

Some critics have argued that the incompatibility between Oil and Vinegar may be overcome by using emulsifying agents as used for example in mayonnaise or vinaigrette. In the case of mayonnaise, lecithin - contained in the yolk of an egg - acts as emulsifying agent. Lecithin dissolves in oil and water and with these properties lecithin can overcome the interface tension between the two phases. However, also emulsions stabilized by an emulsifying agent may become instable if the agent is not deliberately chosen. Then, the emulsions are exposed to flocculation, creaming, coalescence, or Ostwald ripening that alters their internal structure often worsening their properties.

1. The science part of this subsection is due to Rudolf Blankart University of Hamburg. 
As politicians probably have heard of this law of science, they were searching for an institution as emulsifying agent to join the two different governmental fiscal organizations. One may argue that the Maastricht Treaty acts as an emulsifying agent to overcome the interface tensions between German Oil and French Vinegar. However, it has turned out that the Treaty is not enforceable. It is useless to say: let's assume that the Maastricht Treaty works. As long as a theory explaining how the Maastricht Treaty does work is not available, one has to assume that the interface tensions persist causing the actual crisis. Or in other words: a deliberately chosen well-functioning emulsifying agent is still missing and as long as it is not found, as long as the emulsifying egg is missing, interface tensions will persist, and there is no escape from the crisis.

\section{THE FISCAL SYSTEMS OF GERMANY AND FRANCE: A HISTORICAL COMPARISON}

Most authors explain the euro crisis by the economic tension between the North and the South of the euro zone (Sinn 2012). This paper follows that line as well. But it makes the game theoretic interaction between the Oil and Vinegar states explicit [eq. (1) and (2)]. The crisis could be overcome if the Vinegar states can be convinced to become Oil states.

But the Maastricht Treaty shows that this is easier said than done. The governments would not play Oil or Vinegar respectively had they not their own deep reason to behave in that way. Most economists point to historical reasons. But what are the historical reasons that have generated Oil and Vinegar states? If they are assumed to be exogenous then we are back to North and South whose difference is not explained. If institutions are fully endogenous we are confronted with an endless sequence of events each resulting from a previous event. We are in the trap of an infinite regress. Government behavior is not explained either. This paper seeks a compromise. Its goal is to start with as few exogenous variables as possible. Only two exogenous events are assumed: the collapse of the Roman Empire dated 476 and the French revolution of 1789 . These are the corner stones between which the fiscal institutions of Germany and France are explained.

What emerged out of the remains of the Roman Empire were not two nations as Germany and France with own public expenditures and taxes, one Oil and the other Vinegar, but rather the pan-European feudal system, a network of private contracts providing local, regional and interregional security from hordes of bandits and organized enemies roaming through the lands, an insurance system to which the peasants provided labour services (instead of taxes) in exchange for protection by the local knights who provided military support for the vassals, who in turn were in a contract for mutual support by the seigneurs, the kings and the emperor (Volckart 2002). Any distinction between Germany and France, or Oil and Vinegar, is inappropriate here. All political actors had to play Oil in order 
to survive. Their power was based on decentralized real resources of labour and later substituted by tax resources. All these resources were proprietary and so were expenditures and debts. They were a question of rights that passed from one generation to the next. Their path dependence generated stability.

An exogenous rupture of these historically grown traditions occurred in the French revolution of 1789, an event that reversed the whole French fiscal system upside down. The triggering occasion to the revolution came from taxation. Louis XVI, King of France, was in a financial crisis. He convoked the Estates General to Versailles in order to convince them to contribute more tax revenues to the crown.

But the Third Estate took over power in the Estates General and proclaimed itself to be a National Assembly. It abolished the proprietary tax structure of the duchies, counties and other aristocratic jurisdictions and defined the whole country (now subdivided in eighty one administrative départements) as a single tax district. All tax revenues entered into the national pool, and all revenues stood for all expenditures. Though the tax base was increased and more revenue was available than before, the collective decision making on the budget was not simplified. The allocation of revenues and expenditures in a pool required a collective decision making mechanism, which was quite different from the pre-existing ones under of the Ancien Régime. Previously path dependent decisions had channeled revenues and expenditures in a stabilizing way. The revolution, however, manifested itself in the fact that such traditions were shaken off. Without predetermination, however, the budget became a common pool that soon turned out to be the Achilles heel of the budget for, without predetermination, all interests had equal access to the tax resources. It is therefore not clear in what pattern the expenditures should be ranked. Without a collective decision making mechanism, the budget process essentially became a fight of all against all.

The revolutionaries were reluctant to impose new hierarchical structures on the budget that could have been regarded as reactionary: the new Constitution should be open for all interests. Therefore, the Constitution of 1792 requires in article 49 only that the legislative body "decides by a majority of those present." But simple majority rule is too weak, as a principle, to responsibly channel the access to the common pool. Simple majority rule may be able to overcome the fight of all against all and may help avoid tumultuous sessions of the national assembly as recorded from the first years of the revolution, but simple majority is not able to generate a stable ranking of the interests: it can only transform unstructured interests in cycling decisions.

In order to achieve a stable outcome more than just a simple majority is required. Joseph Greenberg (1979) has shown that the required majority $\mathrm{m}^{*}$ to guarantee at least one equilibrium point among all issues, must satisfy the condition $m^{*} \geq[n /(n+1)]$ where $n$ is the number of dimensions of issues (see Mueller 2003 p. 101). If each of the 749 representatives of $1792 / 93$ has only one distinct preference, then a majority of $749 / 750$ or $99.9 \%$ is required to guarantee 
at least one equilibrium point. Hence only a qualified majority with a very high percentage of assent, in fact a near unanimity, can guarantee a stable outcome. On the other hand, the lower the majority the larger is the probability of a cycle ceteris paribus.

But given a simple majority rule, what should a rational representative do if he wants to avoid becoming a victim of a cycling majority of concurrent interests? To make other representatives' preferences more similar is difficult, and consequently the rational representative can try to attract additional resources from outside groups to reduce the budget costs of his project, and hence attract a majority that is large enough to make cycling unlikely.

The Hungarian economist and noble price winner Janos Kornai has observed that in a centralized socialist economy the demand for resources always exceeds the available amount of resources and that hence there is a "run-away" demand which is always on search for soft budgets outside the ordinary resources and hence pursues Vinegar at the costs of third parties. ${ }^{2}$ The following figure 1 shows the calculus of a representative trying to increase the probability of approval of his preferred project by pursuing Vinegar.

The probability of a stable majority outcome is an increasing function of the percentage of off-budget or Vinegar financing. More vinegar increases the probability of national approval. ${ }^{3}$ Therefore Vinegar is inherent in the common pool of the French budgetary process. Six examples are provided for illustration:

Figure 1

How vinegar increases the probability of collective approval

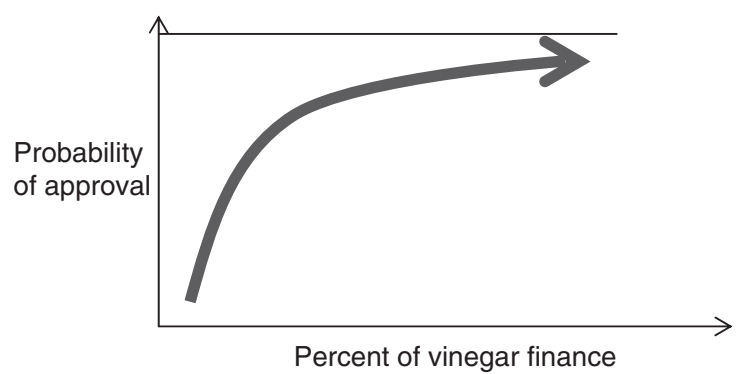

Source: Own compilation

2. "When, however, the budget constraint of many firms [or administrations] is soft, their demand for inputs becomes unconstrained ... run-away demand will appear ... the system becomes a shortage economy." (Kornai, 1986 p. 11).

3. This conclusion has to be seen comparatively to Germany below. 
(1.) A first source of money taped already in 1789 came from the sale of confiscated ecclesiastical properties. As the revenues from these confiscations were not immediately available, the actual budget deficits were financed by "assignats", a paper money "assigned" to these properties. As assignats boosted the money supply beyond the capacity of the economy it generated inflation. Therefore the value of the assignats fell very soon. Already by 1793 , the value of an assignat had dropped to $40 \%$ of its face value. As by 1796, 45 billion livres of paper money had been printed, while the value of ecclesiastical properties was only at 2 to 3 billion livres, the abundance of paper money generated hyperinflation. Vinegar manifested itself by the fact that the national budget deficit has been shifted largely to outside groups; to ecclesiastical properties and groups who held nominal values while the government was able to finance the first coalition war of 1792 by Vinegar. In 1796, the assignats completely lost their purchasing power and were replaced by the "mandats territoriaux" which were just another paper money that also disappeared in 1798 when species re-emerged (Thiers $\uparrow \mathrm{Law}^{4}$ ).

(2.) Additional revenue for financing runaway budgets was collected from plundering defeated countries and from imposing tributes on them in the revolutionary wars. Domestic tasks were effectively externalized to other governments, as predicted by Vinegar.

(3.) In 1800 , the First Consul, Napoleon Bonaparte, took action to stabilize the monetary system. He founded the Banque de France, a private, but publicly dominated stock company, and granted it the right to issue bank notes in exchange for discounted commercial bills first in Paris and later in the whole country. The Bank's obligation to finance government deficits was small in normal times, but large in times of war and revolutions. So the central bank remained in a close link with the government budget over more than one hundred years. After World War II, in December 1945, the Banque de France was nationalized. It became part of the ministry of public finances who issued decrees including decrees to finance the government. ${ }^{5}$ The bank became part of the national budgetary process. Its task to finance the government budget has been made even more explicit in the law of the Banque de France of January 3, 1973, whose article 1 states that "the «Banque de France » is charged by general mandate of the State to control money and credit." "Mandate" means that the bank has to follow the instructions of the national government. All in all, financing by money creation was the governments' preferred choice after tax financing and

4. See Bernholz (2005).

5. Art. 22 of the Law of December 22 December 1945.

6. Law of the Banque de France of January 3, 1973 : "La Banque de France est l'institution qui, dans le cadre de la politique économique et financière de la nation reçoit de l'Etat la mission générale de veiller 
hence, the French national debt, especially war debt, remained small compared the public debt of other countries such as the UK. The mandate of $1973 \mathrm{had}$, however, to be discarded as a consequence of the Maastricht Treaty and replaced the principles of non-monetization of the ECB System in $1993 .^{7}$

(4.) The constraints of 1993 on the Banque de France were severe and difficult for the government. Missing tax revenues had now to be replaced by public debt. But debt was much less comfortable than money creation. Debt did not disappear after a year, but remained on the books of the nation, in the records of the European Union and in the memories of the financial markets. The new Law of the Banque de France of 1993, which prohibits money creation, therefore imposed an enormous stress on the French government. Without money creation, France was supposed to reform its institutions and play Oil. Its adjustment costs (see equations (3) and (4)) would have been excessive: France had to give up its identity inherited from the revolution. It is therefore not surprising that the French government searched for ways to get around the Treaty instead of abiding by its rules.

(5.) As budget externalization over the national central bank was no more feasible after the Maastricht Treaty, the question arose on what might be the next best alternative of Vinegar financing. Since the early years of the European Union the EU budget revealed itself as a willing host for French vinegar as it allows to shift a burden on the shoulders of the community. In 1966 already the French government succeeded in shifting the major part of its agricultural budget on the EU budget. Another way of vinegar policy is national indebtedness via Eurobonds for which all member states are jointly liable. For the time being Eurobonds are welcomed by the French president, but vetoed by the German government because of their enormous moral hazard effect. ${ }^{8}$ But they may be implemented under a future political coalition. Actually Eurobonds have to be substituted by legal alternatives such as loans from The European Stabilization Mechanism ESM or from the Target2 payment system of the ESCB (Sinn, 2012 and Blankart and Klaiber, 2012).

sur la monnaie et le crédit. A ce titre, elle veille au bon fonctionnement du système bancaire." Légifrance December 28, 2012 : http://www.legifrance.gouv.fr/affichTexte.do?cidTexte=JORFTEXT 000000334815\&date Texte $=19931231$

7. Art. 1 "La Banque de France fait partie intégrante du Système européen de banques centrales" etc. http://www.legifrance.gouv.fr/affichTexteArticle.do;jsessionid=BC7DFD1BA7650DE1AD60C451298 ABEEE.tpdjo15v_2?idArticle=LEGIARTI000006696954\&cidTexte=LEGITEXT000006082477\&date Texte=20130527 May 272013 .

8. President Hollande http://www.spiegel.de/international/europe/french-president-fran-ois-hollande-to -call-for-euro-bonds-at-eu-summit-a-834180.html (May 13, 2013) 
(6.) Finally, on the national level, the French decentralization policy from 1980 to 2010 has to be seen as an outflow of Vinegar. In course of this reorganization, many budgetary tasks that were traditionally in the national responsibility sphere were decentralized to the subcentral levels of government (to the regions, the départements and the local authorities). But the national government only partially granted the resources that were needed by the subcentral governments to finance these tasks. It played successfully Vinegar: former national tasks were externalized to lower level governments who had to increase their taxes. For the average French citizen, therefore, the effect of the decentralization movement was that he had to pay higher taxes. Business reacted by reducing its local investments mainly due to the increased local business tax, and as a consequence the national government had to abolish the local business tax (the "taxe professionnelle") in 2010.

Equation (5) below summarizes the essence of the French budget. The left hand side shows the national common pool, in which all revenues stand for all expenditures. As this pool is chronically too small (for the reasons given above), the remaining financial requirements are shifted off budget onto the public debt, the European Union and other third parties including subcentral governments. The pressure to generate such residual sources must be enormous given that money creation as the first best alternative is no longer available under the new law.

$$
\begin{aligned}
& \text { ( } \left.\sum \text { expenditures }\right)-\left(\sum \text { tax revenues }\right) \\
& \quad=(\text { government debt }+ \text { externalities to third parties such as } E U) .
\end{aligned}
$$

Now we are left to explain why the German institutions generate a budget that is different from the French budget. When France introduced its national budget in 1789 Germany was a pure confederation consisting of 327 sovereign territories, which resulted from the Middle Ages and codified in the Treaty of Westphalia of 1648, under the roof of the Holy[5 RP DQEmpire. Each prince had his power, which rested on his territoriality, sovereignty and legitimacy. The idea of national revenues that had to be allocated to common goals as in France just had no substance in Germany as there was no nation. ${ }^{9}$ Large style paper money issuance could not be sustained in the German territories either as they were too small for such aberrations. The governments played Oil because they had no access to Vinegar. Budgets were fractioned, proprietary and exempt from any interjurisdictional subsidization. Crossborder picking of resources was out of the question. Proprietary taxes represented fixed endowments of each sovereign.

9. Except the "Reichskammerzieler" a poll tax to finance the expenditures of the "Reichskammergericht" (the Supreme Court). 
This system was stable though not necessarily efficient. Efficiency would have required the addition of interjurisdictional competition.

It is true that the French revolutionary wars of 1792 to 1814 also affected the political structure of the German territories: the 327 sovereign territories merged to 39 sovereign states by 1815 . The roofs became larger, but budgets remained separated. The later Kaiserreich remained decentralized with only national defense, social security costs and budgets being federal. Even today's Federal Republic of Germany is far from a unitary state. Although the German taxes are under federal regulation, German taxes are not national as in France. German taxes consist of rights that are shared by the Länder and the Federation. Germany has not a national, but only an aggregated budget whose aggregation is calculated mainly for statistical reasons and for comparison with other countries. ${ }^{10}$ The actual aggregated budget consists of a federal budget, 16 state budgets and about प०.૫00 local budgets plus the parafiscal budgets as can be seen in equation (6). The aggregated budget of Germany is balanced if each subcentral budget is balanced in expenditures $=$ revenues + own debt.

$$
\begin{gathered}
\text { Federal budget }+\sum_{1}^{16} \text { state budgets }+\sum_{1}^{0000} \text { local budgets } \\
+\sum_{k=1}^{n} \text { parafiscal budgets }=\text { aggregated budget }
\end{gathered}
$$

No government can tap on another government's budget and neither can it attract resources from the central bank. Intergovernmental fiscal equalization is tied to rules reflecting particular rights. Following a decision of the German Federal Constitutional Court, the federal fiscal equalization must not change the rank order of the fiscal endowments of the subcentral states, the "Länder". Leapfrogging is not permitted which imposes stability to the German fiscal system (Blankart 2011, ch. 29). These assigned endowments create property rights which limit rent-seeking in other governments' purses. Moreover interstate fiscal equalization in Germany is - as opposed to French practice - not earmarked whereas French fiscal equalization is mostly earmarked and hence "the long arm" of the national budget. ${ }^{11}$

10. The aggregate budget has an important indirect relevance. Commission and Council of the European Union treat all member states as if they were unitary states. EU and euro negotiations take place for Germany and the other federal member states as entities though they are not unitary states. This implies a permanent implicit violation of their constitutions.

11. Some examples of earmarked transfers in France are: The "dotations de fonctionnement" according to population and surface, "dotations d'équipement" for selected investments, "dotations de compensation" for regional planning, "dotations de solidarité" for poor cities, "dotations de solidarité locale" for local and regional cohesion, "dotation minimale de soin" minimal public service level esp. for health to enumerate but a few. Interest groups therefore strive to obtain entitlements within the existing 
Table 2

The Institutional organization of the public budgets in Germany and in France

Feudal system

Middle ages proprietary security system; many territories

\begin{tabular}{|c|c|}
\hline Germany 1648-2013 & France 1789-2013 \\
\hline 327 / 39 / 16 Territories ${ }^{12}$ & 1 Territory \\
\hline 327 / 39 /16 Budgets & 1 Budget \\
\hline Fractioned proprietary rights in taxes & 1 National tax authority \\
\hline Fractioned proprietary tax bases & 1 National tax base \\
\hline Fractioned debt bases & 1 National debt base \\
\hline Fractioned budgets & $\begin{array}{l}1 \text { common pool, simple majority, budget } \\
\text { shortage }\end{array}$ \\
\hline No money creation for budgets & National money creation up to 1993 \\
\hline Path dependent budget balancing: Oil & $\begin{array}{l}\text { Runaway demand, deficit, pressure to } \\
\text { externalize fiscal burdens: Vinegar }\end{array}$ \\
\hline $\begin{array}{l}\text { Art. } 20 \text { para. } 1 \text { Basic Law: "The Federal } \\
\text { Republic of Germany is a ... f federal state." }\end{array}$ & $\begin{array}{l}\text { Constitution Art. } 2 \text { "La France est une } \\
\text { République indivisible ...?" }\end{array}$ \\
\hline Oil & Vinegar \\
\hline
\end{tabular}

Source: Own compilation. ${ }^{13}$

To this date, fractioned rights are a core constitutional principle in Germany. The Federal Republic of Germany cannot be transformed, even by constitutional amendment, in a unitary state. Art. 20 of the Basic Law (the Grundgesetz) irrevocably states that "The Federal Republic of Germany is a . . . federal state". These federal principles have been given up in War times from 1914-1918 and from 1939 to 1945 . But they have been restored in 1924 and 1949.

Table 2 above summarizes the comparative budget institutions in Germany and in France in their historical development. The table is self-explanatory from the text above. The reader may begin its reading with the feudal system in the center of the top line, move down left to Germany and then look on the right hand side to France.

dotations or to establish new dotations. The "dotations globales d'équipement" e.g. depend on the size of the population of the locality, on whether it is a joint public work of several localities and on the size of the population of the respective département either in metropolitan France or overseas. Channeling in dotations as such does therefore not change the nature of the French budgetary process. The dotations are not constitutional, but part of the budgetary process within common pool financing.

12. $1648 ; 1815 ; 1990-$

13. It should be emphasized that German and French budgets do not differ because Germans and Frenchmen are different or because they have different tastes. This paper is not in any sense pro- or anti-German or -French. The paper follows the paradigm of Garry S. Becker and George Stigler (1977) who say: "De gustibus non est disputandum!" In an economic analysis, whatever are human tastes, individuals are constrained to behave differently under different institutions. Their budgetary choices differ because their institutions differ and not because their tastes are different. Given the institutions, Germans and Frenchmen could be exchanged as a whole, and the same budgets would result. 
Table 2 illustrates the budgetary dichotomy between Germany and France since the French revolution up to the German Basic Law (the "Grundgesetz") of 1949. Germany had a proprietary budget system, whereas France had a national common pool budget engendering budget shortage, rent-seeking and budget externalization by vinegar all over the years since the revolution. Budget financing via national money creation was among the most important sources of French vinegar policy. After this source has been blocked in the Maastricht Treaty Vinegar over the European Monetary Union became of primary importance.

For practical purposes the subsequent decades up to the euro crisis have been divided in two parts: in a euro negotiation period until 1992 in section IV and a euro decision period from 1992 up to the euro crisis in section V.

\section{THE EURO NEGOTIATION PERIOD UNTIL 1992}

The European Monetary integration has been a dream of French European policy since World War II. As early as 1949 the former French minister of public finance Jacques Rueff has coined the adage: “L'Europe se fera par la monnaie ou ne se fera pas" ${ }^{\prime 14}$. These words remained a leading principle of the French policy up to present. But principles rarely have an end in itself. They usually originate from interests.

\section{IV.1. The French dilemma}

The French position can be described as follows. Consider an economy as depicted in figure 2 and follow the small dotted path in the centre. A relatively small GDP such as $\mathrm{GDP}_{1}$ is feasible under a budget deficit $(\mathrm{G}-\mathrm{T})$ in the upper right hand quadrant but it requires capital imports [Cap. Import (G-T)] shown in the upper left quadrant which are feasible under a relatively high rate of interest (below left) which, again, is compatible with $\mathrm{GDP}_{1}$ in the upper right hand quadrant. The small dotted path represents the equilibrium.

Now assume that the French government aims at a higher $\mathrm{GDP}_{2}$ and follow the solid small dark path: With a larger deficit $(\mathrm{G}-\mathrm{T})$ a larger $\mathrm{GDP}_{2}$ becomes feasible. But $\mathrm{GDP}_{2}$ requires more capital imports (dotted dark black line): If these capital imports are not generated by the market, the country falls back even below $\mathrm{GDP}_{1}$. Hence there is no positive welfare effect for the country to run deficits. Of course, more capital could be attracted if France conducted a more market oriented policy with less central planning. But France preferred to argue that there is a capital import gap, so to say a market failure. If only someone provided capital as indicated by the curly bracket the French situation could look

14. Van Raepenbusch (2005). 
Figure 2

The French dilemma of capital import shortage

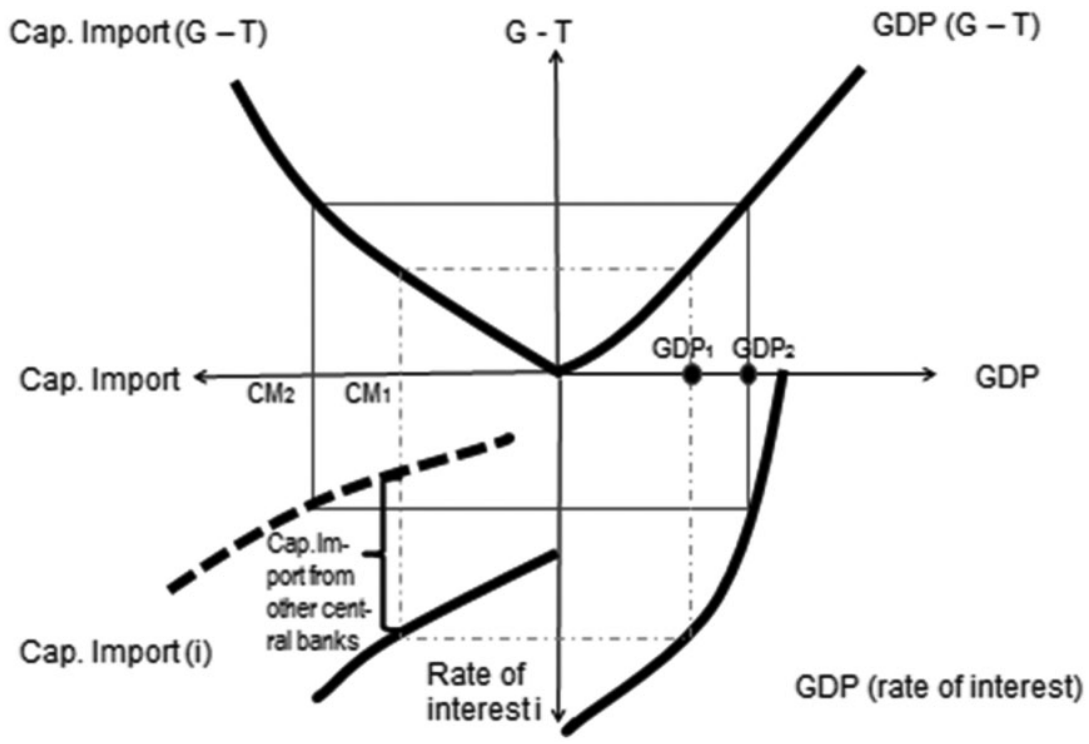

Source: Own design

much sunnier. But what could that mean? In the old days of the Latin Monetary Union (1865 to 1926), which was dominated by France, it was tolerated that a country filled its capital import gap by printed bank notes as long as the mandatory gold content of the coins was maintained. So, printed money became a common pool resource allowing Vinegar policy for the participating countries. But these romanticized days are passés. New ways for practicing Vinegar had to be invented. ${ }^{15}$

\section{IV.2. Bretton Woods}

The real masters of Vinegar policy were, however, not the French, but the Americans with the System of Bretton Woods 1944. They achieved that practically the whole Western world paid for the US balance of payments deficit. Though it was never intended that Bretton Woods provided a common reserve pool, an initial weakness in its design opened this loophole.

15. In fact, however, money printing was one of the main causes why the Latin Monetary Union eventually collapsed. 
According to the rules of Bretton Woods every participant country had to maintain a fixed exchange rate of its currency to the US Dollar while the US committed to sell or buy 1 ounce of gold for 35 US Dollars presented by a national central bank belonging to the system. Therefore Bretton Woods is often called a gold-Dollar-standard. In order not to lose Dollars or gold, all Bretton Wood states had an incentive to balance their fiscal accounts without the money printing press, in short to play Oil. But Bretton Woods had a leak. The United States could print as many Dollars they wanted, however, at the risk of losing their gold reserves if too many paper dollars were presented by the other central banks. This was indeed the critical point of Bretton Woods.

Under the pressure of the public expenditures for the Vietnam War and for the project of the "Great Society" the United States decided first to postpone and on August 15, 1971, to stop the conversion of Dollars into gold. In fact the US played Vinegar, while the partner governments were supposed to play Oil. Some years later the partner governments made up their minds and decided to no longer comply with the rules of Bretton Woods which thereafter collapsed on March 11-14, 1973.

\section{IV.3. The mechanism of the Snake}

Though the deficiencies of Bretton Woods became visible long before its end, the idea of a World or European monetary order has exerted a great fascination among economists. Robert Triffin (1960) has pleaded for a European common currency whose central bank acts as a reserve pool that compensates deficits and surpluses of national capital imports and exports. The consequence of the Triffin plan was that France could play Vinegar with large budget deficits such as $(\mathrm{G}-\mathrm{T})$ in figure 2 , overcome $\mathrm{GDP}_{1}$ and reach the larger $\mathrm{GDP}_{2}$. Therefore the Triffin plan was highly welcomed in France. The burden of financing the budget deficit, which was previously carried by the Banque de France, could now be shifted to a European central bank. It was all too obvious that the Deutsche Bundesbank should carry the lion's share of this reserve pool. But the Bundesbank said no. It argued that according to German law it is not allowed to transfer German reserves to an international organization (Maes 2002).

The coming decay of Bretton Woods and the German unwillingness to pay for other countries' balance of payment deficits induced the EU Council in 1970 to adopt the principle of parallelism of the "Werner Plan" (named according to the former Prime minister of Luxemburg). The EU states agreed to narrow their exchange rate fluctuations, within the exchange rate band of Bretton Woods (the tunnel) not exceeding $+/-2,25 \%$ to the US Dollar on the one hand and to pursue an economic policy supporting this exchange rate stability on the other. A first version of this currency cooperation was the "snake in the tunnel" of December 1971 in which the EU states agreed to stay within the band of Bretton Woods (the 
tunnel). When Bretton Woods eventually collapsed in March 1973, the members of the snake decided to pursue the goal of exchange rate stability alone "outside the tunnel" of Bretton Woods.

The regime of the snake was quite rigorous. A participant state who did not succeed in parallelism and was not able to keep its exchange rate within the agreed band could receive a 3 months guaranteed repayable monetary assistance up to 1,4 bn. ECU to recover. ${ }^{16}$ The participant state automatically dropped out of the snake when it failed to comply with the standard within the given time limit. There was no option to become a permanent participant of the snake without strict compliance to the exchange rate requirements. Only a few countries succeeded to sustainably abide by these rules. France was among the first that dropped out. Eventually only Germany, the Benelux and Denmark managed to stay in the snake. The snake was a very exclusive club, but too small to be of economic relevance.

\section{IV.4. The European Monetary System EMS}

The snake had proven that a country cannot run a budget deficit (according to figure 2) and remain a member of the snake. Its balance of payments would become negative and the exchange rate would transgress the allowed band with the consequence that the country had to leave the snake. President Valéry Giscard d'Estaing of France, who was finance minister during the years of the snake, was aware of this. He visited Chancellor Helmut Schmidt of Germany in 1978 in order to convince him to extend the currency assistance of the snake openendedly. He meant that this had to be seen in anticipation of a future European monetary union whose central bank should be equipped with enough money to maintain fixed exchange rates. Consequently, the idea of a currency buffer pool reappeared through the backdoor. It was rejected immediately by the Bundesbank and somewhat later by the German Federal government (Bernholz 1998, p. 797-815). The future European Monetary Union should not simply be an instrument to balance French balance of payments deficits. The French side could hardly understand the German position: for the French, a central bank that does not act as a reserve pool is useless. The German side disagreed. After some discussions back and forth both sides agreed to a four stage program for countries that had problems of maintaining their exchange rates:

- First: A short run repayable financial support program inherited from the European Currency Snake at 11 bn. ECU.

- Second: A medium term repayable financial support program of another 11 bn. ECU.

16. Actually 1,4 bn. European Currency Accounting Units (later ECU) (s. Bernholz 1998 p. 792 ). 
- Third: A realignment of the exchange rates should take place if a fundamental exchange rate disequilibrium occurs.

- Fourth: An automatic exit occurs if the first three remedies do not succeed.

Figure 3

Exchange rate fluctuations of the EMS currencies and the Pound Sterling in percentage terms yearly mean values from $1979-1998^{18}$

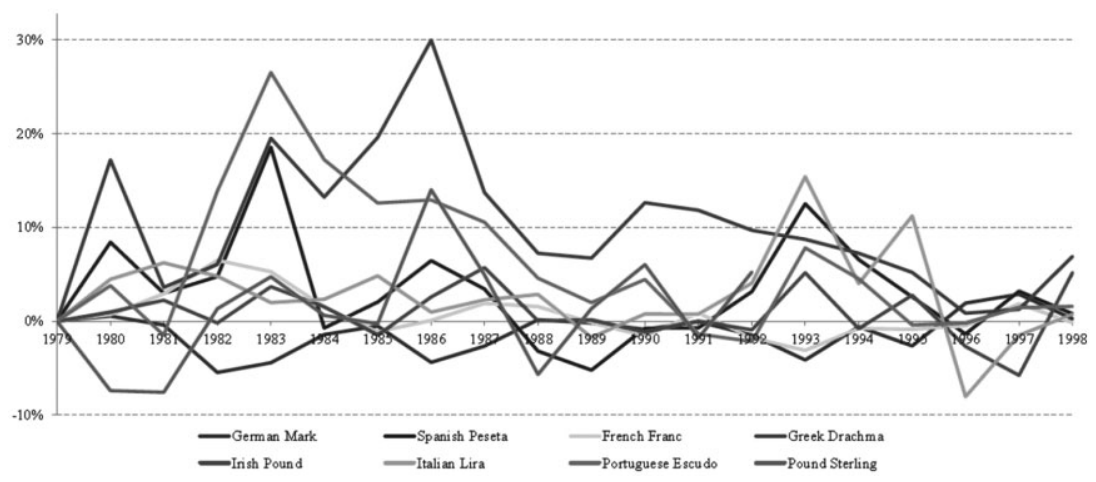

Source: Own compilation from Eurostat

The EMS was a good compromise to unite Oil and Vinegar countries. France was not constrained to completely abandon its fiscal system inherited from the past, but was warned not to overuse it. It could count on monetary support, but it was made clear that support was limited and repayable. It is often argued that the EMS failed in the currency crisis of 1992/93 and that the EMS was deficient, but this is not correct. A closer look reveals that the crisis occurred because the UK and Italy, which were hit by balance of payment deficits, resisted a realignment of their exchange rates according to the third stage of the above mechanism and therefore had to leave the EMS according to stage four. France was in a similar situation, but it enforced a widening of the exchange rate bands to $+/-15 \%$ and therefore escaped realignment.

That the EMS was a success can be seen from figure 3, which displays the decline of exchange rate volatility over the 20 years of its existence. ${ }^{17}$ It is true that other factors such as the expectation of the euro and the endeavour to fulfill the Maastricht criteria contributed to the favourable performance of the EMS. Nevertheless, it can be seen from figure 3 that good rules can contribute to

17. The standard deviation developed from $7,1 \%$ (1980) to $11,0 \%$ (1986) to $7,4 \%$ (1993) to 2,7 (1998) (own calculations).

18. Pound Sterling until 1992. 
monetary stability. Helmut Schlesinger, who was president of the Deutsche Bundesbank from 1991 to 1993, commented in 2012: „This system could have been continued without any problems" (Schlesinger 2012, translated by the author).

\section{IV.5. Passing the point of no return at Hanover and Madrid}

Although the EMS generated stability among the European currencies, it was disliked by the French public opinion and by the French government as it was clear that the D-Mark was its anchor currency to which all other EMS currencies were attached. This comes from the logic of the EMS:

- If $n-1$ countries of $n$ participant countries of a fixed exchange rate union intervene to maintain their exchange rates at the agreed level, the exchange rate of the n-th country is also fixed whatever its monetary policy.

- The n-th currency will be the reserve currency.

- Which country will be the n-th country whose currency becomes the reserve currency depends on its reputation. In order to be on the safe side the EMS member states attached themselves at the country with the highest reputation for price stability. This was the D-Mark.

- So the D-Mark has become the n-th and the anchor currency for all other EMS participants.

In practice, it turned out that what has been decided Monday by the Bundesbank in Frankfurt was implemented Tuesday in Amsterdam, Brussels, Vienna and last, but not least, in Paris. Whenever the Bundesbank increased the rate of interest, France had to follow and this was exactly what the French authorities disliked. So German "Oil" domesticated French "Vinegar". But the French government felt uneasy. It wanted to have the Bundesbank out of the EMS and pleaded instead for a joint pluralistic monetary policy of all EU countries reducing the pressure on its budget policy (recall the capital import gap in figure 2 and see Lindenlaub 2009).

At the summit of Hanover in 1988, the France seized the opportunity to raise its concerns on the EMS. The Council, recalling its decision on a European monetary union taken in the Single European Act of 1986 gave the French issue a new and farther-reaching momentum. ${ }^{19}$ It entrusted a committee of "technocrats" consisting of the President of the European Commission, Jacques Delors, and the 12 presidents of the national central banks a mandate to elaborate a plan towards a European Monetary Union.

The Delors Commission proposed a normative model on how they thought a European monetary constitution should look like and how such a constitution

19. Delors Report (1989) p. 1, and see Marsh (2009, ch. 5). 
should be attained. It should have a politically independent European Central bank (later Art. 282 TFEU) based on the principles of non-monetization of public debt (Art. 123, 124 TFEU), of no-bailout of public finances (Art. 125 TFEU), national budget balancing (Art. 126 TFEU), price stability (Art. 127 TFEU) and be implemented in three progressive steps. The Delors Commission's output was the design of a monetary order that was consistent. But the Commission did not discuss the question whether and how all these principles could be enforced once the common currency has started when a government preferred to defect. The consistency of Delors' conclusions (not their enforcement) was discussed and approved at the following summit of Madrid, on 26 and 27 June 1989. It has also been decided in Madrid that Delors' first stage towards the European Monetary Union shall start the July $1^{\text {st }} 1990$. The details had to be formally prepared later by the EU Monetary Committee and accepted by Ecofin and finally approved at an Intergovernmental Conference. ${ }^{20}$

The Delors report and the ensuing Maastricht Treaty can be characterized as too much French and too little British: they were too much Cartesian and too little Hume'ian. A discussion on how the treaty should be enforced once it was approved was avoided and compliance was assumed but not explained. Furthermore, a violation of the core principles (Art. 123-125 and 127 TFEU) remained without any sanction. Sanctions were only discussed for violations of the budget

20. There is a dispute on the role of the summits of Hanover of June 1988 and Madrid of June 1989, on the one hand, and the following summit of Strasbourg of December 1989 on the other. The former two relate to the monetary union exclusively, while the latter opens a link to the German unification. On the one hand it is clear that Hanover has brought the decision to charge Commission's president Delors with designing a plan to come to a European Monetary Union (and hence to abandon the EMS), that Delors' report has been accepted by the summit of Madrid and that it was decided there that the first stage of the Monetary Union will start July $1^{\text {st }} 1990$. Steps 2 and 3 required, however, an Intergovernmental Conference (ICG) that approved the amendments of the Treaty concerning the monetary union. After step one has been decided it seems inevitable that decisions on 2 and 3 must follow. With Madrid, the point of no return to the monetary union was passed. France, which was most interested in the monetary union (for the reasons given above), wanted that the IGC starts early and it is conceivable that President Mitterrand insisted in an ICG conference in 1990 at the summit in Strasbourg of December 1989. The opportunity for such a fixing of the date was favourable because Germany's most important goal was now the German reunification by the end of 1989. Therefore Chancellor Kohl's yes to an IGC in 1990 was easy to obtain. Apparently most of the other participants of the summit had no objection either. The interpretation, however, that Mitterrand threatened Kohl in a night and fog deal that he will stop the reunification unless Kohl said yes to the monetary union in its entirety seems highly exaggerated and unfounded: how could Mitterrand really stop the German reunification? The $2+4$ talks of September 1990 (with the two Germanies, the US, USSR, UK and France) were obviously not an appropriate place. On the other hand Chancellor Kohl had a large number of excuses to delay the Monetary Union at the IGC in December 1990 if he wanted to do so. Jacques Attali, who argues that "[i]t is thanks to French reticence ... that we have got the common currency", and Hubert Védrine who argues similarly seem to glorify ex post the French policy without great substance; but see Vaubel (2010) and Sinn (2012) for opposing views. It seems much more plausible that Kohl wanted to create a double monument for himself of being the Chancellor of the reunification as well as the chancellor of the monetary union. 
deficit criterion (Art. 126 TFEU) but even in this case, sanctions were thought only after a Council decision that in reality was never taken.

A pluralistic element that entered the Treaty was the ECB Governing Council that consists of the Members of the ECB Board and the Presidents of the national central banks. The Council is primarily responsible for price stability but can, without prejudice, also pursue other aims of "general economic policy" (Art. 282 para. 2 TFEU). The participants avoided to ask the question what will happen when the Council postponed its core principles in favour of the "general economic policy". Hence monetary and fiscal policies were not clearly separated. ${ }^{21}$

To summarize: The Maastricht Treaty is a perfect exercise on paper. Logically constructed it is based on the assumption that all member states comply with the rules, that all play Oil and stand for their own costs. The problem of adjustment costs of equations (3) and (4) is disregarded. The Treaty is constructed as if the monetary union is a cooperative game.

In the following section $\mathrm{V}$ the author will show that as France was not able or willing to comply with the Treaty after the signing, its government enforced ex post changes in such a way that national fiscal burdens could be shifted as Vinegar to the Union. This was a signal for moral hazard, state bankruptcies and the unfortunate rescue programs disseminating depression, unemployment and hate in many member states.

\section{THE EURO DECISION PERIOD FROM 1992 TO THE EURO CRISIS}

\section{V.1. Dismantling the Maastricht Treaty}

Eventually the Treaty of Maastricht was solemnly signed by the Heads of State and of Government including President François Mitterrand of France on 7 February 1992. It seems that at this very moment, it must have become clear to president Mitterrand that France was unable to comply with the rules of Maastricht which were in full contradiction with the tenets of French political tradition: (1.) No deficit financing by the Banque de France; (2.) Instead a fear of having excessive deficits and debt on the capital market; (3.) Deficits and debt would be limited by the Maastricht criteria; and (4.) Last but not least, a bankruptcy being possible without a bailout. If France really were to comply with Maastricht it would have had to give up the centralized tax and budget system, the core of achievements of the French Revolution and to return to self-responsibility of the subcentral units, in fact, to become a federal state comparable to Germany. Therefore President Mitterrand decided that France

21. The tension between price stability and "general economic policy" became obvious when the European Central Bank was charged with the supervision of the union credit institutions (art. 127 para 5 TFEU) in the Council decision of April 18, 2013. 
would not adjust its rules to Maastricht, but that the rules of Maastricht should be adjusted to France. Four important adjustments of the (already signed) Treaty were on Mitterrand's agenda:

1. Making the ECB instrumental (V.2)

2. Political staffing of the ECB (V.3)

3. Eliminating the no-bailout clause (V.4)

4. Making Germany a partner in this endeavor (V.5).

Empirical evidence for each item of this agenda will be provided in the remainder of this section.

\section{V.2. Making the ECB instrumental}

The Maastricht Treaty could become law in France only if it passed the referendum proposed to the French voters on 20 September 1992. The voters were very skeptical on the Treaty, and the referendum was about to fail for the president. Therefore, Mitterrand thought that he had to make a special effort. He launched a television broadcast on 3 September 1992 in which he explained the Treaty to his citizens. In order to calm the situation he injected some of his old reservations. He put not only the principle of central bank independence into question. He even reversed it. He said:

"[J']entends dire partout . . que cette Banque Centrale Européenne sera maîtrise [indépendante] de ses décisions! Ce n'est pas vrai! La politique monétaire appartient au Conseil Européen et l'application de la politique monétaire appartient à la Banque Centrale, dans le cadre des décisions du Conseil Européen." 22

In other words: "There is much arguing that the ECB will be independent. This is simply not true!" he said. The monetary policy is to be formulated by the European Council and is to be executed by the ECB. It cannot be overlooked, and it is certainly not accidental, that the president has chosen the wording of the law on the Banque de France of 1973 (see footnote 6). He only inserted "le Conseil Européen" in lieu of "la nation". This shows that he was willing replace the Maastricht Treaty of type C by a Treaty of type B. An incredible affront against all euro partners, but fully consistent with homo oeconomicus of equations (1) and (2).

Though the referendum passed with a majority of $51 \%$ it was not clear whether the French voters voted for Mitterrand's version of the Treaty or for the official version. In summary: The referendum was good for generating an ambiguity and to put into question the independence of the European Central Bank.

22. Quoted from Issing (2008, p. 53). 


\section{V.3. Political staffing of the ECB}

But the president pronounced only words. Deeds had to follow and did follow. In order to make the ECB really political the right persons had to be placed in the relevant positions of the ECB.

A key position is, obviously, that of the president of the ECB. In May 1996 the governors of the national central banks (NCB) elected Wim Duisenberg, the governor of the Bank of the Netherlands, with approval of the great majority of the heads of state or government for the position of President of the European Monetary Institute EMI successively the President of the ECB. In opposition to this decision, already taken, President Chirac of France insisted in November 1997 that there be a second vote. ${ }^{23}$ In this second vote, the European Council failed to reach unanimity because President Chirac insisted on Claude Trichet as president of the ECB despite Duisenberg having already been elected. After a distressing discussion between President Chirac and the other heads of government, it was agreed in May 1998 that Duisenberg would step down from his office after four years (at most) and that Trichet would hold the position thereafter for eight years. ${ }^{24}$ This swap resulting from French blackmail was illegal because (1) an existing decision has been cancelled with less than unanimity and (2) because the Treaty requires that the office of the President of the ECB lasts eight and not only four years (art. 109a (2) (b) EC or art. 283 TFEU) (Warleigh 2002). Nevertheless it is evidence for the author's Vinegar hypothesis that the Maastricht Treaty had to be and was illegally adjusted ex post to the French demands.

Trichet, once in office, became independent of the French president, and also independent of the European Council (insofar president Mitterrand and his successor Chirac were not able to fully enforce their position), but Trichet remained loyal to the French conception of a central bank that eventually could also rescue national governments in deficit. During the first half of his tenure, Trichet was restricted in his discretion by the regulations of the Maastricht Treaty and the still treaty-abiding majority of the ECB governing council. With the banking crisis of 2007/2008, however, the majority of the ECB governing council changed its position. The members of the council became hungry for credits for their countries regardless of the legal regulations. The political demand for money encouraged Trichet to use his power as an agenda setter, to put the issue on the agenda of the ECB governing council and to let it approve and to start his securities markets programme (SMP) consequently monetizing public debt for some states at the costs of all states.

23. 17 May 1995 Jacques Chirac has become president of France.

24. In any case, Trichet could not step in earlier because he was under investigation over his role in scandals at French bank Credit Lyonnais. 
Firstly, Trichet's purchasing program clearly violates art. 123 TFEU which says:

"Overdraft facilities or any other type of credit facility with the European Central Bank or with... public undertakings of Member States shall be prohibited, as shall the purchase directly from them by the European Central Bank or national central banks of debt instruments."

In addition the European Council clarified in 1993: "purchases made on the secondary market must not be used to circumvent the objective of that Article" 25 which means that purchases of euro government bonds by the ECB are clearly prohibited, irrespectively of whether they come from a member state directly or indirectly through an intermediary. Without prejudice, the bank may, however, purchase non-euro securities without limit for the purpose of monetary policy (Homburg 2012). Secondly, Trichet's purchases of euro government bonds under the SMP programme have been approved by a majority of the ECB governing council (under opposition of the German members Axel Weber and Jürgen Stark who withdrew under protest). ${ }^{26}$

These purchases open an interesting problem of public choice theory. What happens if the Treaty says "no" and the ECB governing council decides a "yes", i.e. if the purchases were illegal, but nevertheless made? Apparently the purchases were in the national interest of the majority of the ECB governing council states, but not in the interest of the enforcement of the Treaty. What should be done? In order to cancel an illegal majority decision, someone has to bring a charge before the European Court of Justice. The theory of low cost decisions predicts, however, a decision of courtesy by the court given the high costs of the plaintiff and the low costs of the judges (see Kirchgässner 1992). So it was in the case of the Irish charge in 2012. Often therefore the "yes" of a majority of a committee, such as the ECB governing council, is stronger than the "no" of a regulation. The "yes" creates a new status quo whereas the court decision can at best reinstall a former status quo.

The German negotiators of Maastricht apparently disregarded this asymmetry of collective decision making. They thought that the ECB regulations are part of the Treaty which will be self-enforcing. They thought, as the regulations cannot be changed, that the German tenets in the European monetary union are not in danger. It has been argued that regulations in the Treaty are even stronger than the regulations of the former Bundesbank (Scharrer 1992, p. 212). But nobody asked how these strong regulations should be enforced. The German negotiators could not imagine that the regulations could simply be disregarded and overthrown by a simple majority of the ECB governing council, and that nobody would stop it. The German government disregarded this point when they

25. Council Regulation (EC) No 3603/93.

26. So Axel Weber became persona non grata in the Elysée and was dropped by France as a candidate for ECB presidency in favour of Mario Draghi. 
negotiated Maastricht and hence accepted an enormous asymmetry in the Treaty in favour of Vinegar countries.

Although Germany contributed $40 \%$ of the working capital to the ECB (Sinn and Feist 2000), it missed to secure a relative majority in the governing Council of the ECB. Had it enforced a vote of $40 \%$ in the ECB governing council or a respective veto right, the SMP programme would have barely been possible. Apparently the decisive vote for the SMP programme ended with $11: 11$ in May 2010 with Trichet casting the final ballot, and $12: 11$ in the vote of September $2010 .{ }^{27}$

\section{V.4. Abolishing the no-bailout clause}

Up to 2008 only the first two points of Mitterrrand's agenda of adjusting the Treaty (V.1) were implemented. But the danger that France may slide into a national bankruptcy was still pending. Trichet became aware that the ECB alone could not rescue a large nation such as France.

The Ecofin Council decided 7 October 2008 that in case of a new banking crisis, for the time being, the nation states are responsible for their system relevant banks. ${ }^{28}$ But could France carry such a burden without going bankrupt? Was this principle sustainable? Vinegar commands that such risks must be shifted to other states.

The Greek crisis of 2010 made this issue apparent. As Greece became insolvent at the end of April 2010, the European Council decided that the no-bailout clause of art. 125 TFEU shall neither directly be applied nor directly be violated, but that the Greek budget deficit shall be distributed on all Euro-member states.

But the Greek program was only the first step. One week later a bailout scheme encompassing all euro states was established by the heads of state and government in their summit of 7/8 May 2010. The no-bailout principle of art. 125 TFEU, a core principle of the European Monetary Union, was put aside and replaced by discretionary policy. How was this possible? How could a Treaty, which was negotiated for over 15 years, simply be eliminated in one night? ${ }^{29}$

Reviewing a detailed report of the summit by Peter Ludlow (2010), it is apparent that Claude Trichet was again the driving force. Trichet was not a member of the summit but he participated as a guest ${ }^{30}$ and took the opportunity to start the session by explaining the situation of the European government bond

27. Following estimates by Vaubel (2012).

28. Economic and Financial Affairs Council, Luxembourg, 7 October 2008 http://www.consilium.europa .eu/uedocs/cms_data/docs/pressdata/en/ecofin/103250.pdf (17 mai 2013).

29. Even the French finance minister Christine Lagarde and the French minister of European affairs Pierre Lellouche conceded that the Treaty has been violated by the European Council 7/8 Mai 2010, see: Frankfurter Allgemeine Zeitung, Nr. 300, 24. December 2010, p. 13.

30. Art. 284, para. 2 TFEU. 
markets with help of PP slides. He scared the participants by describing a drastic picture of the market and especially for the peripheral euro countries. Indeed, government bond rates declined during the first half of the week as apparently the Greek bailout did not provide market confidence. The rates further declined during the second half of the week. But rates recovered again when the German Bundestag formally approved the Greek bailout program Friday 6 May 2010. Notwithstanding this situation, Trichet warned of a pending disaster that might happen when the Tokyo stock exchange would open on Monday 10 May 2010. Trichet disseminated fear, a very effective and costless instrument for which he had to take no responsibility, as no one can predict what the stock exchange really would do. So Trichet brought the Council to the decision that the ECB should be unburdened from the problem of rescuing EU member states alone, that a pan-euro bailout umbrella should be established and that the no-bailout clause should no longer be applied. In fact, he convinced chancellor Merkel to design a common rescue plan and to assume the lion's share of the costs.

President Sarkozy of France warned that France will leave the euro zone if Germany did not agree, and indeed France was the winner of the day for the French commercial banks were heavily engaged in Greek government bonds as well as in government bonds of other peripheral euro member states: the guaranteed bailout of these countries helped the French commercial banks to survive. To put it differently: without the European bailout the French national government would have been responsible for France' systemic banks according to the Ecofin decision of 7 October 2008 mentioned above. But now, after the summit of 7/8 May 2010, the French burden was socialized on the euro level. Vinegar triumphed over Oil.

Finally it was agreed that $60 \mathrm{bn}$. euro for this scheme come from the Commission, ${ }^{31}$ a second tranche of $440 \mathrm{bn}$. euro from the euro member states, and last but not least, a tranche of $250 \mathrm{bn}$. euro should come from the IMF, in total 750 bn. euro.

What is most remarkable, though predictable, is that the first bailout of Greece has triggered a bunch of further bailout programs: the provisional EFSF, EFSM and IMF packages of 7/8 May 2010 of $750 \mathrm{bn}$. $€$ were supplemented by another provisional EFSF of 780 bn. $€$ in 2011 and by the permanent ESM of 800 bn. $€$ in 2012. This latter's volume exceeds the annual EU budget by about factor 6,5 without counting the Target 2 loans to peripheral countries and to France of actually about 705 bn. euro (see Sinn and Wollmershäuser 2012 for a general assessment). This spiral documents how, under Vinegar, national problems are shifted to the euro level where they are incorporated in a larger budget. The fact

31. Whose financing was far from evident; for there was no funding for such payments (see Blankart, Koester 2012). 
that some participants play Oil while others play Vinegar unleashes an enormous potential of moral hazard. As the donor governments, first of all Germany's, were reluctant and accountable for these expenditures before their parliaments, they prescribed strong austerity programs on the bailed out governments causing significant unemployment, depression and hate. As euro common pool financing makes such actions feasible, it prevents that the governments in financial distress exit out of the euro. It precludes devaluation and imposes pain without a perspective of improvement on these countries. This is the tragedy of the euro crisis.

\section{V.5. Germany and France in a prisoner's dilemma}

In sections II, III and IV, the author has provided empirical evidence that Vinegar breaks the contract $\mathrm{C}$ because option B is in its advantage. Given B as the new status quo, Oil's best response is to break the contract too. So the game ends in the bilateral defect of solution D.

Such a situation was given under the euro in 2005. Germany and France both violated the deficit criterion of the Stability and Growth Pact as part of the Maastricht Treaty antecedently in the years 2002 and 2003 and hence triggered the excessive deficit procedures of the European Commission in 2004. But Chancellor Schröder of Germany, together with President Chirac of France, launched a Council decision in 2005 to reinterpret the pact in a more flexible way. The deficit and debt limits remained unchanged, but 15 exemptions have been approved defining what the word "excessive" means. As a result the pact lacks any limits. De facto, this was an ex post change of the Treaty outside the rules, hence a cross-default D.

\section{V.6. The tragedy of the euro crisis in a nutshell and why a political union does not help}

After having described the behaviour of the German and French governments in practice, a return to the theoretical model of section II is indicated. A summary of this model is displayed in the well known prisoner's dilemma diagram of figure 4.

Oil and Vinegar maximize their joint benefit of 80 or 40 each if they agree to the Treaty $\mathrm{C}$, the Maastricht Treaty and comply with these rules. By agreement to Maastricht, they also reveal that solution $\mathrm{C}$ brings in more than what each of them can make under the economic union E. But given C, France becomes also aware that defecting from $C$ and playing $B$ yields an even larger payoff 45 at the costs of Germany's Oil whose payoff is reduced to 30. Given Germany's defeat before French Vinegar, it is the best for Germany to defect too and to play 
Figure 4

Oil and Vinegar in a prisoner's dilemma

\begin{tabular}{|l|c|c|}
\hline euro with & France Oil & France Vinegar \\
\hline Germany Oil & C 40/40 & B 30/45 \\
\hline Germany Vinegar & (F 45/30) & $\downarrow$ (D 32/42) \\
\hline
\end{tabular}

Source: Own compilation

Vinegar leading to the payoffs of 32 and 42 for Germany and France respectively in cell D. A glance at figure 4 reveals that there is no escape from the equilibrium $\mathrm{D}$ which represents the truth of the euro crisis.

It is true that the prisoner's dilemma is usually considered as a simultaneous game. The players anticipate that the Maastricht Treaty will be broken and go directly to D. But one can also describe it as a sequential prisoner's dilemma from $\mathrm{C}$ over $\mathrm{B}$ to $\mathrm{D}$ which makes sense as the countries start from an Economic Union E. ${ }^{32}$

Sometimes it is argued that the problems of the euro monetary union could be overcome in a euro political union. An exogenous enforcer appears who imposes Oil/Oil or Vinegar/Vinegar on the two countries. In the first case drastic punishments are imposed on France if it defects from $\mathrm{C}$ towards B. It has, however, been shown earlier in this section that France did not accept such infringements in its sovereignty in the case of the monetary union. Therefore it is unlikely that it will accept them in a political union. The second case involves the anarchic solution D for both countries which is presumably rejected by Germany. Thus it can be concluded that if the political union cannot be achieved and that the Maastricht Union has proved not work too. Hence only the European economic union remains as a reasonable alternative.

\section{CONCLUSIONS}

The paper started with Oil and Vinegar as two independent countries. Oil pursues a policy of stable prices, Vinegar prefers an inflationary policy. Both can coexist in a friendly manner in an economic union in which the two governments "go Dutch", and each pays its bill with its own currency at the given market exchange rate. In a currency union, however, Oil and Vinegar enter in a common cash management allowing Vinegar to exploit Oil under solution B unless Oil enforces its own rules on Vinegar under solution $\mathrm{C}$. But $\mathrm{C}$ is only stable if an

32. That Germany will switch from $\mathrm{C}$ immediately to $\mathrm{F}$ is unlikely as Germany has already played oil under the Bundesbank rule. 
enforceable contract effectively protects Oil's property from Vinegar's intrusion. The experience with the Maastricht Treaty has, however, shown that solution $\mathrm{C}$ is not a stable solution as Vinegar can switch to its first best alternative B. With $\mathrm{B}$, Vinegar not only benefits from the resources drawn from Oil, it also saves the adjustment costs of its institutions should the Maastricht Treaty be enforced and Vinegar then would have to adopt a balanced budget stability policy under the Oil central bank.

If solution $\mathrm{C}$ fails a hybrid system $\mathrm{D}$ situated between $\mathrm{C}$ and $\mathrm{B}$ will emerge which generates fiscal externalities in that governments mutually shift their fiscal burdens onto each other's shoulders and hence promote moral hazard, government bankruptcies, bailouts, rescue and austerity programs, depression, unemployment and hate, as largely described in the ongoing literature of the euro crisis. It is, in fact, the euro at its worst.

The lesson of this tragedy is that we have already gone too far into the monetary union. If solution $\mathrm{C}$ is not feasible because the contract is broken and the union moves to D we should ask for the advice by Ronald Coase (1960) who might refer to his farmer rancher paradigm and say to the two wranglers: Eliminate your externalities by establishing property rights and then go on and trade! If, however, your externality comes from a non-tradable public good such as a currency union, then do not try to continue this union. Eliminate the externalities by withdrawal from the currency union which is the source of the externality and establish your own currency, but maintain the economic union! So you can realize mutual gains of trade and avoid detrimental externalities.

Withdrawal from the currency union will be supported by Oil who has already revealed its preference for $\mathrm{E}>\mathrm{D}$ (see section II). Vinegar, however, may be reluctant to return to the economic union as it loses the benefits from Oil's transfers leading to B > E for Vinegar. But Oil is not at the mercy of Vinegar. Oil can unilaterally slow down the transfer payments to Vinegar and to its fellow vinegar states and so induce the Vinegars to become self-sufficient. As transfers dry out, Vinegar and its associates may be induced to introduce parallel currencies to the euro whose proper working is subject to actual research (see Mayer, 2012 and Meyer, 2012).

\section{LITERATURE}

Attali, J. see Vaubel (2010).

Becker, G.S. and G.J. Stigler (1977). De Gustibus Non Est Disputandum, American Economic Review. 67(2): 76-90.

Bernholz, P. (1998). Die Bundesbank und die Währungsintegration in Europa, in Deutsche Bundesbank (ed.), Fünfzig Jahre Deutsche Mark. Notenbank und Währung in Deutschland seit 1948. München: Beck: 773-833.

Bernholz, P. (2005). Die Bedeutung der Geschichte für die Wirtschaftswissenschaften und der ökonomischen Theorie für die Geschichtsforschung, Perspektiven der Wirtschaftspolitik. 131150 . 
Blankart, Ch. B. (2011). Öffentliche Finanzen in der Demokratie (Public Finance in a Democracy), $8^{\text {th }}$ ed, Munich: Vahlen.

Blankart, Ch.B. (2012). Euro: Preis der deutschen Einheit? Finanz und Wirtschaft. 85(9): 3

Blankart, Ch. B. and A. Klaiber (2012). EZB, ESM und Target2, Schweizer Monat. (999): 23-25.

Blankart, Ch. B. and G. Koester (2012). The Lisbon Treaty, the financial crisis and a way out of the EU Budget Gridlock, in G. Benedetto and S. Milio (eds.), European Union Budget Reform. Institutions, Policy and Economic Crisis. Basingstoke: Palgrave (Macmillan) Houndmills: 79-95.

Bozo, F. (2007). Mitterrand's France, the End of the Cold War, and German Unification: A Reappraisal. London: Routledge: 455-478. http://www.jhubc.it/FULLEVENTCAL/UPLOADFILE2/Bozo \%20paper.pdf accessed 30 January 2013.

Churchill, Sir Winston (1946). Zurich Speech of 19th September 1946. Strasbourg http:// assembly.coe.int/Main.asp?link=/AboutUs/zurich_e.htm (16 June 2013).

Coase, R.H. (1960). The problem of social costs, Journal of Law \& Economics. 3: 1-44.

Delors, J. (1989). Report on economic and monetary union in the European Community. Brussels, presented April, 17, 1989.

De Grauwe, P. (2006). What Have we Learnt about Monetary Integration since the Maastricht Treaty? Journal of Common Market Studies. 44(4): 711-730.

Greenberg, J. (1979). Consistent majority rule over compact sets of alternatives, Econometrica. 47: 627-636.

Homburg, St. (2012). Illegal und undemokratisch, Wirtschaftswoche. (44): 43.

Kornai, J. (1986). The soft budget constraint, Kyklos. 39(1): 3-30.

Kirchgässner, G. (1992). Towards a theory of low-cost decisions, European journal of political economy. 305-320.

Issing, O. (2008). Der Euro. Geburt - Erfolg - Zukunft. München (Vahlen).

Lindenlaub, D. (2009). Zehn Jahre Euro, in Deutsche Bundesbank (ed.), Für eine stabile Gemeinschaftswährung - Die Bundesbank in der Geschichte der europäischen Währungsintegration. Frankfurt.

Ludlow, Peter (2010). The European Council and the euro crisis, Eurocomment. 7(7/8): 1-59.

Maes, I. (2002). Vom Reservefonds zur Zentralbank, in La Libre Belgique, 26. October.

Marsh, D. (2009). The euro - The Politics of the New Global Currency. London: London and Oxford Group; German: Der Euro. Die geheime Geschichte der neuen Weltwährung, Hamburg: Murrmann.

Mayer, Th. (2012). Der Geuro. Eine Parallelwährung für Griechenland, Die Parallelwährung: Optionen, Chancen, Risiken. Berlin: Bundesverband mittelständische Wirtschaft: 65-68.

Meyer, D. (2012). Nationale Parallelwährungen als Königsweg, in D. Meyer, (ed.), Die Zukunft der Währungsunion. Chancen und Risiken des Euros. Berlin, Münster: Lit Verlag Dr. W. Hopf: 259-276.

Mitterrand, F. (2008). see: Issing O.

Mueller, D.C. (2003). Public Choice III. Cambridge: Cambridge Univ. Press.

Van Raepenbusch, S. (2005). Droit institutionnel de l'Union européenne. Bruxelles: De Boueck \& Larcier, s.a..

Scharrer, H.-E. (1992). Probleme einer europäischen Wirtschafts- und Währungsunion nach Maastricht, Hamburger Jahrbuch für Wirtschafts- und Gesellschaftspolitik. Tübingen: Mohr: 2007-224.

Schlesinger, H. (2012). EZB-Geldflut erinnert an die Kriegsfinanzierung, (Interview) Die Welt, March 10, p.1.

Sinn, H.W. (2012). Die Target Falle. München: Hanser.

Sinn, H.W. and H. Feist, (2000). Der Euro und der Geldschöpfungsgewinn: Gewinner und Verlierer durch die Währungsunion, ifo Schnelldienst. 53(31): 14-22.

Sinn, H.W. and T. Wollmershäuser (2012). Target Loans, Current Account Balances and Capital Flow: The ECB's Rescue Facility, International Tax and Public Finance. 19(4): 468-508. 


\section{CHARLES B. BLANKART}

Triffin, R. (1960). Gold and the Dollar Crisis. New Haven: Yale University Press.

Volckart, O. (2002). Wettbewerb und Wettbewerbsbeschränkung im vormodernen Deutschland. 1000-1800. Tübingen: Mohr.

Védrine, H. see Vaubel (2010)

Vaubel, R. (2010). The Euro and the German Veto, Econ Journal Watch. 7(1): 82-90.

Vaubel, R. (2012). Die Politische Ökonomie der Staatsschuldenkrise und die Zukunft Europas, in D. Meyer, (ed.), Die Zukunft der Währungsunion. Chancen und Risiken des Euros. Lit Verlag Berlin: 83-102.

Warleigh, A. (2002). Understanding European Union Institutions. London: Routledge.] 